\title{
Knowledge management capability as an absorptive for driving innovation: The role of type of innovation
}

\author{
Muhamad Robith Alil Fahmi ${ }^{*}$ and Edy Yulianto ${ }^{a}$
}

${ }^{a}$ Faculty of Administration Science, Brawijaya University, Indonesia

\section{H R O N I C L E}

Article history:

Received: December 14, 2020

Received in revised format:

January 292021

Accepted: March 2, 2021

Available online:

March 2, 2021

Keywords:

Knowledge Management Capabil-

ity

Innovation Type

SMEs Performance

\begin{abstract}
A B S T R A C T
Knowledge-Based View as an intangible resource for the company will become the knowledge capability it possesses. Particularly in the context of SMEs in developing countries like Indonesia, SMEs have a big role in contributing to the country's economy. Therefore, knowledge capability is a resource that must be owned by SMEs that should be able to encourage adopting this type of innovation. In accordance with the basis of Knowledge-Based View, this knowledge will have an impact on company performance and its competitive advantage through the types of innovations that have been adopted. The quantitative method was used by distributing questionnaires totaling 120 SMEs in Indonesia and the data were processed using PLS-SEM. This study has a hypothesis that the relationship between knowledge management capability has a positive and significant effect on firm performance, as well as the mediating role of the type of innovation. The results in this study indicate that knowledge management capability does not have a significant effect on firm performance. However, the relationship between knowledge management capability shows that it has a significant effect on marketing, product, process, and service innovation. Discussions related to these results are also explained by implication factors in this study.
\end{abstract}

\section{Introduction}

Based on the perspective of the Knowledge-Based View, it considers knowledge as the most strategic resource of a company with the potential to generate sustainable competitive advantage and company performance (Soto-Acosta et al., 2016; Martinez-Conesa et al., 2017). Even in the Knowledge Economy and Society, knowledge is characterized by economic globalization, the emergence of technological advances in several industries and there is a progressive advantage from technologybased industrial markets to become a resource to compete. Through good management of intellectual resources (knowledge), companies have the ability to innovate and have a sustainable competitive advantage (Cabrilo \& Dahms, 2018). Meanwhile, in the last decade, many companies have made efforts to improve their innovation capabilities, as innovation drives market competitiveness in today's rapidly changing environment (Ferraresi et al., 2012). Including the SME sector which must be more competitive through creating innovations because it can be the key in terms of sustainability and business performance (Price et al., 2013). In the context of the SME sector, the aim of knowledge inflows and outflows is even more relevant for sustainable competitiveness because the SME sector will face more crucial resource constraints (Dahlander \& Gann, 2010; Spithoven et al., 2013). Therefore, knowledge that is used as a resource can later create innovation (Martín-de Castro, 2015; Mardani et al., 2018), both in terms of processes (methods), products, markets, and services as stated in Theory of Innovation by Schumpeter (1934).

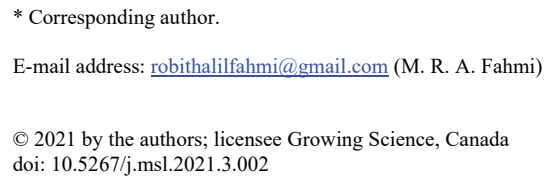


Schumpeter (1934) introduced Theory of Innovation as an important factor for long-term company success. Innovation can be classified as product innovation (providing new or better goods or services), process innovation (providing new methods or methods and combinations in the production process), marketing innovation (introducing new products / services to the target market) (Wadho \& Chaudhry, 2018; Gronum et al., 2012; Exposito \& Sanchis-Llopis, 2019; Ramadani et al., 2019). Various types of innovations can be applied by a company but depending on their abilities it can be seen from their knowledge, capacity, and even the type of company sector and the characteristics of the company (Mamun, 2018; Phan; 2019). As in an increasingly uncertain environment, companies must push to innovate on various types of innovations in order to survive and grow. Several previous studies have tested and proven that the implementation of these types of innovation (product, service, process, and marketing) can have an influence on company performance (Exposito \& Sanchis-Llopis, 2019; Ramadani et al., 2013; Mamun, 2018; Phan, 2019; Rajapathirana \& Hui, 2018; Park \& Kwon, 2018) which is the basis of this research.

In this study, which refers to the existing literature and data, it is assumed that Small and Medium Enterprises (SMEs) have an important and major role in their contribution to building the Indonesian economy. It is proven from data from the Indonesian Central Bureau of Statistics that Indonesian SMEs have contributed to the country's economy by 60 percent of Gross domestic Product (GDP). So, the development of SMEs carried out by the Indonesian government can support the acceleration of quality economic growth by running a productive economy (BPS, 2019). However, many SMEs experience obstacles in developing their businesses due to the lack of innovation (Mamun, 2018). Finally, many businesses cannot survive, then go bankrupt since the products or services offered are not strong or cannot compete. In Indonesia, many SMEs only run a business regardless of their potential. SMEs are expected to be able to think critically and be innovative in producing goods and services by utilizing knowledge capabilities (Hock-Doepgen et al., 2020). Even though the goods offered are of the same type, if each has significant differences, it creates consumers have many choices. Especially since the economic and health crises that are being experienced in various countries have caused stability and disruption to their performance. This impact is a nuisance for SMEs in Indonesia which have designed SME development strategies. Thus, this research focuses on Knowledge Based View as a resource seen from Knowledge Management Capability to carry out company innovation. Therefore, innovation studies, especially in the context of SMEs, are important because of the uniqueness of the processes and resources owned by the company, and its role in innovating that results in corporate sustainability and performance, as well as national development.

\section{Literature Review}

\subsection{Knowledge-Based View}

The knowledge-based view (KBV) provides benefits for strategic management and company operations (Foss et al., 2013), marketing strategy (Li et al., 2010), and knowledge management on employees (Gardner et al., 2012). KBV Pressed the study of knowledge-based resources, which refers to the use by which companies combine and change the input of tangible resources (Gassmann \& Keupp, 2007). Knowledge-Based View argues that knowledge-based resources are an important determinant of a firm's capacity to generate substantial competitive advantage (Caputo et al., 2019). There is a dimension that can create a sustainable competitive advantage and outperform competitors, namely a performance dimension that may need to coexist. The main point of knowledge-based view Kogut and Zander (1992) and Grant (1996) argued that in general the presence and configuration of appropriate knowledge leads to higher levels of performance as Barney's perspective (1991). Knowledge and capability development is a widely discussed area in the organizational knowledge management literature (Schütz et al., 2020), largely rooted in a knowledge-based view. While about knowledge capability development was a widely discussed area in the organizational knowledge management literature (Schütz et al., 2020), largely rooted in a knowledge-based view. So, in a knowledge-based view, knowledge is the company's most strategic resource. Based on this argument and in line with the knowledge-based view that knowledge is a strategic intangible resource for companies (Grant, 1996). In line with that perspective, knowledge-based view, proper implementation of knowledge and the configuration of that knowledge should drive performance (Barney, 1991; Grant, 1996).

\subsection{Knowledge Management Capability}

Barney (1991) argued that companies can gain a sustainable competitive advantage from their controllable resources and capabilities, which are valuable, scarce, imperfect, and irreplaceable. Knowledge resources can be treated as unique and valuable resources that are used for a company's competitive advantage based on the Resource-Based View (RBV) approach of firm (Barney, 1991; Karkoulian et al., 2013; Wu \& Chen, 2014). Prior to that, in the discussion of RBV and the extension of Knowledge-Based View (KBV) (Guillen, 2000; Rivard et al., 2006; Spender, 1996), the approach to properly understanding Knowledge Management performance must be rooted in the identification of knowledge resources, namely knowledge assets and knowledge process capabilities. Thus, Knowledge Management has attracted a lot of attention, and has even shifted into a superior knowledge resource in addition to human resources and physical resources for the company. The importance of companies managing knowledge is the basis for having capabilities in creating more competitive competitiveness in the market (Hock-Doepgen et al., 2019). Capability refers to an organization's ability to collect, integrate, and implement valuable resources (Wu \& Chen, 2014). Helfat and Peteraf (2003) describe resources as tangible or intangible assets that are owned, controlled, or accessed by an organization. Discussion of resources and capabilities, knowledge is part of intangible assets which will certainly be able to build and create company capabilities when considered as resources. 
Many companies have used their knowledge skills to innovate because it was seen as a way to compete. In the context of SMEs that are faced with the ability of innovation capacity which can be seen from the type of innovation applied and besides that it is used to compete in the market, so it must have good performance (Mamun, 2018). This means that more and more companies have taken advantage of innovative practices supported by efficient and effective knowledge management capabilities for the benefit of the company. As well as the influence of knowledge assets such as intellectual capital on company performance through the role of innovation created (Exposito \& Sanchis-Llopis, 2019; Ramadani et al., 2019). Several empirical studies have examined the influence of various aspects of knowledge-based assets and KM on innovation produced by companies. Other studies have focused more on knowledge-based assets and how ownership of these assets is associated with corporate innovation. For example, Wang and Chen (2013) found that institutionalized knowledge and codified experience (i.e., organizational capital) and knowledge-based interactions between individuals and company networks (i.e. social capital) on innovative abilities, both incremental and radical innovation. In addition, it can be said that knowledge management is involved in the process of creating innovation through the development of new ideas and exploration and exploitation of intellectual resources (Dahiyat, 2015; Martinez-Conesa et al., 2017). Meanwhile, several other studies have focused and highlighted the effects of knowledge capabilities seen as intellectual resources on the output of a company's type of innovation (Exposito \& Sanchis-Llopis, 2019; Cammarano et al., 2019). By utilizing Knowledge Management Capability, it can encourage progress on this type of innovation to be a major part of supporting the business innovation process in increasing company competitiveness (Grillo et al., 2018). Companies by innovating in their processes will be able to create a product and service that is more unique and different than its competitors (Al-Saidi et al., 2017). In addition, marketing innovation will play a role in distributing the value of products and services to the target market segment (Ramadani et al., 2019). The results of knowledge management have a positive and significant impact on types of innovation (product, process, service, and marketing) according to several previous studies (Al-Saidi et al., 2017; Mamun, 2018; Inkinen et al., 2015; Zhao, 2020). Based on previous literatures, this research proposes the following hypothesis:

\section{$\mathrm{H}_{1}$ : Knowledge Management Capability influences positively and significantly on Marketing Innovation. $\mathrm{H}_{2}$ : Knowledge Management Capability influences positively and significantly on Product Innovation. $\mathrm{H}_{3}$ : Knowledge Management Capability influences positively and significantly on Process Innovation. $\mathrm{H}_{4}$ : Knowledge Management Capability influences positively and significantly on Service Innovation. $\mathrm{H}_{5}$ : Knowledge Management Capability influences positively and significantly on Firm Performance.}

\subsection{Type of Innovation}

Innovation occurs as a result of a combination of the company's knowledge and absorption ability to reconfigure the company's capabilities and competencies (Al-Saidi et al., 2017). In understanding innovation, various other studies focus on knowledge management capability to determine innovation capability and the type of innovation used (Birkinshaw et al., 2008). Schumpeter's Theory of Innovation (1934) has classified the types of innovation, namely product, process, marketing, and service innovation which are able to have an influence on company performance. In the classification of existing types of innovation, other research has further developed types of innovation, such as using product, process, marketing, and organizational innovation as types of innovation (Rajapathirana \& Hui, 2018; Gunday et al., 2011). In this study, it is a type of innovation aimed at large companies and the manufacturing sector so that there is also a need for innovation in terms of organization. While the SME sector will be different, such as the types of innovation that can be used are product, service, and process (Al-Saidi et al., 2017; Mamun, 2018; Exposito \& Sanchis-Llopis, 2019). And this research considers that the SME sector can also adopt a type of marketing innovation, because it is closely related to pricing strategies, product design properties, product placement, and promotional activities (Gunday et al., 2011). This is due to the existence of the internet of things which can encourage higher marketing activities, even switching to not only offline, but also online (Santoro et al., 2018; Quaye \& Mensah, 2019). In the SME sector, marketing innovation is one type of innovation that is widely used to transform products (Soltani et al., 2015) and also determines the focus of company innovation (Woschke et al., 2017). So, based on previous literature, it shows that marketing innovation can have an effect on increasing sales through the distribution of information on the value of a product and service (Gunday et al., 2011; Wadho \& Chaudhry, 2018; Altuntas, et al., 2018; Quaye \& Mensah, 2019).

Another type of innovation that can be adopted by SMEs is product innovation. Product innovation focuses on increasing efficiency or reducing costs with the aim of attracting customers to buy these products (Al-Sa'di, 2017). This product innovation also increases firm's ability to survive with shorter product life cycles, demand instability, and rapid technological changes (Rajapathirana \& Hui, 2018; Mamun, 2018). However, product innovation can also be determined by the firm's innovation process. Process innovation comes from internal production objectives, and that includes reducing production costs and increasing the quantity and quality of output to be produced (Mamun, 2018). The success of product innovation depends on the production process, so Benner and Tushman (2003) show that production process activities have a positive effect on effectiveness in increasing company innovation. Therefore, efficiency in controlling process innovation which includes all changes that occur in processing methods, so as to improve product quality, which allows flexibility in production functions, labor productivity, which results in a sustainable competitive advantage in performance for the firm (Rowley et al., 2011; Rajapathirana. \& Hui, 2018). Meanwhile, service innovation focuses on creating new value through service design and delivery methods (Toivonen \& Tuominen, 2009). Hertog et al. (2010) revealed that the service innovation capacity of a company varies with its ability to understand market needs and technology choices, to conceptualize (customer reaction to service 
innovation), and combine capabilities (new configurations of existing elements), to produce together. and set it up (fast innovation service). Service innovation provides opportunities for companies to gain a competitive advantage by offering products and services combined with the right solutions (Mamun, 2018). According to Flikkema (2008) service innovation is referred to as a multidisciplinary process in designing, realizing and marketing combinations of existing and / or new services and products that are tested to create customer experience value. With the innovation carried out by the company through the process, it will be able to create new and innovative products and services to be able to improve company performance as measured by the level of sales, profit, investment value, and market process (Al-Saidi et al., 2017; Mamun, 2018; Exposito \& Sanchis-Llopis, 2019). The following is the hypothesis proposed in this study:

$\mathrm{H}_{6}$ : Product Innovation influences positively and significantly on Firm Performance.

$\mathrm{H}_{7}$ : Process Innovation influences positively and significantly on Firm Performance.

$\mathrm{H}_{8}$ : Service Innovation influences positively and significantly on Firm Performance.

$\mathrm{H}_{9}$ : Marketing Innovation influences positively and significantly on Firm Performance.

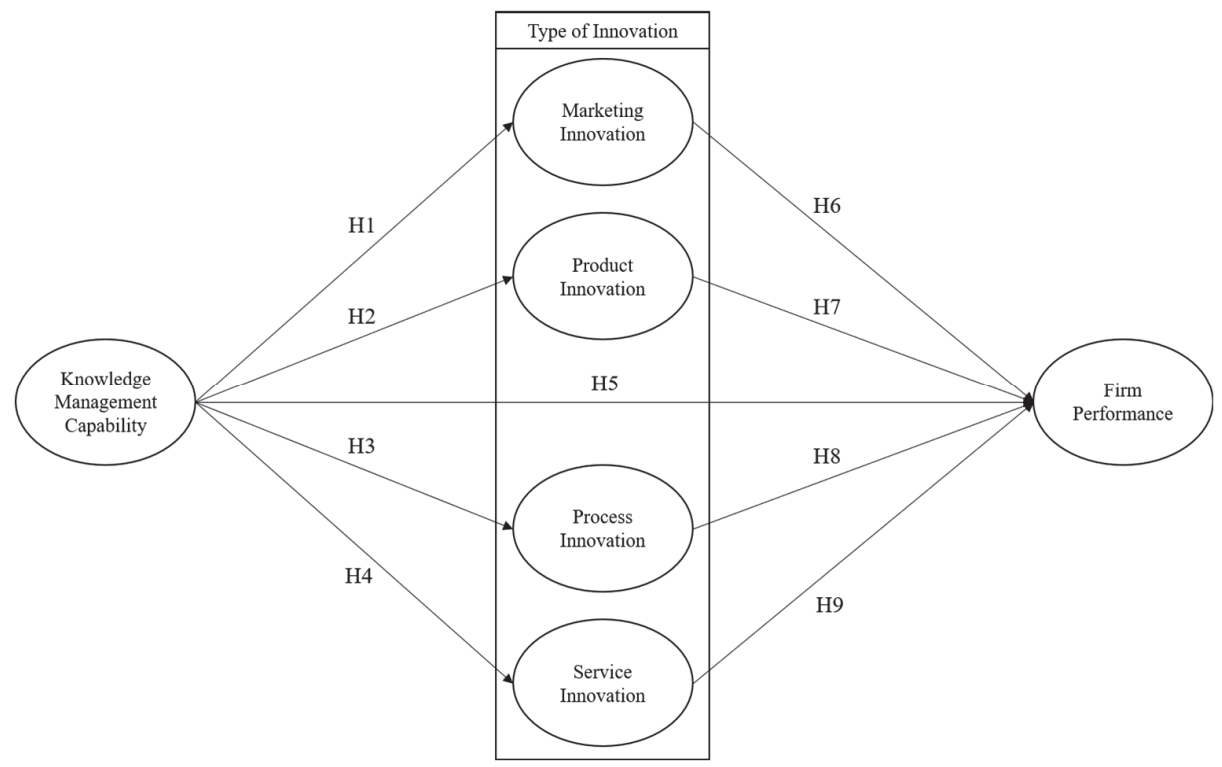

Fig. 1. The structure of the proposed study

\section{Method}

This study uses a quantitative approach through distributing questionnaires to SMEs in Malang City with a total sample of 120 SMEs both small, medium and large scale, but only filling out the questionnaire on small and medium scale. The study also uses statistical analysis where PLS-SEM is a causal modeling approach and aimed at maximizing the explained variance of the dependent latent constructs. Due to the explanatory nature of this study, this study used variance-based-PLS-SEM estimation with the primary objective of maximizing the explanation of variance in the structural equation model's dependent construct. It is a potent statistical tool because it can be applied to all data scales, does not require many assumptions, and confirms relationships that do not yet have a strong theoretical foundation (Hair et al., 2014). Not only that, but PLS is also used to develop or construct hypotheses, predict complex situations, and a feature that facilitates multivariate data analysis; it differs with previous SEM based on proof of theory with parametric assumptions that must be met (Hair et al., 2019). The measurement of reliability in PLS-SEM uses Cronbach's $\alpha$ and composite reliability with standardized indicator loading 0.70 , while the validity uses average variance extracted (AVE) with value of acceptable more than 0.50 , as recommended by Hair et al. (2014). The questionnaire was designed based on previous research in similar contexts and adopting the measures of construct. For instance, knowledge management capability was measured from seven items that Mao et al. (2016). Product (three items), service (three items), and process (four items) innovation was measured from Mamun (2018). Finally, firm performance was measured from four items developed by Hanaysha (2020). All of the adapted items were measured on a Likert scale ranging from strongly disagree to strongly agree.

\section{Result and Analysis}

This study presents demographic data (see Fig. 2) of 120 SMEs as respondents in this study showing that male respondents are the most dominant $(\mathrm{n}=82,68.3 \%)$ and women $(\mathrm{n}=38,31.7 \%)$. From the overall classification of the last education respondents can show knowledge that can represent in this study, the tendency lies in the classification of education SMA / equivalent $(\mathrm{n}=68,56.7 \%)$. Meanwhile, the measure referred to as SMEs in Indonesia also looks at the number of employees, where of the total respondents the most with employees have less than 10 employees $(n=97,80.8 \%)$. 


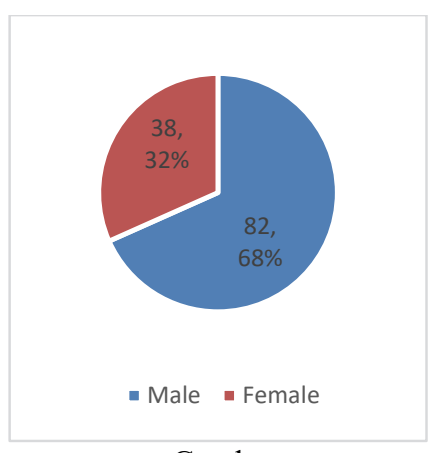

Gender

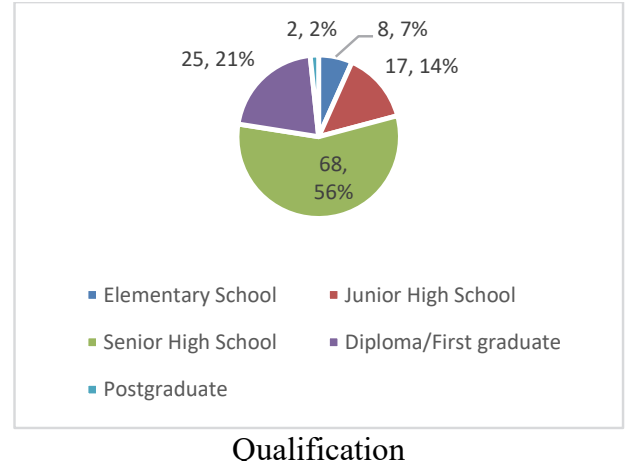

Qualification

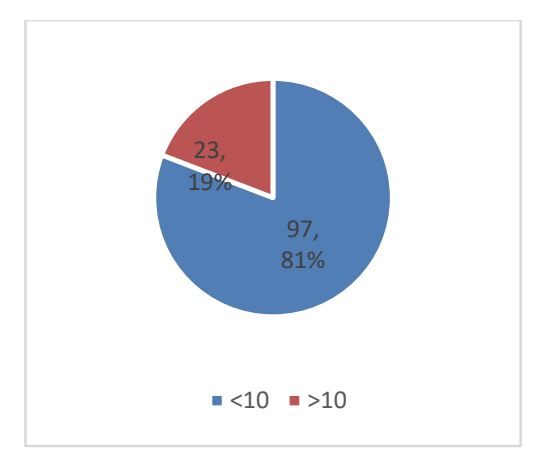

Number of employees

Fig. 2. The number of employees

This study also categorizes SMEs based on Law Number 20 of 2008 concerning Small and Medium Enterprises (UKM) which classifies SMEs into several criteria shown in Table 1 and classification is based on the average of turnover and total of assets measured at the rupiah value. Based on these results, it shows that the dominant tendency is based on the classification of small business types with an average turnover of 50 million to 500 million and with an asset value of 300 million to 2.5 billion $(\mathrm{n}=95,79.17 \%)$. Meanwhile, those in the middle classification category with an average turnover of 500 million to 10 billion and an asset value of 2.5 billion to 50 billion are the second largest $(n=25,20.83 \%)$. In the classification of large business types, there were no respondents who became respondents in this study.

Table 1

Classification of SMEs in Indonesia

\begin{tabular}{|c|c|c|c|c|}
\hline Type of SMEs in Indonesia & Average of Turnover & Total of Assets & Frequency & $(\%)$ \\
\hline 1. Small Business & $50-500$ million & 300 million $-2,5$ billion & 95 & 79.17 \\
\hline 2. Medium Business & 500 million -10 billion & $2,5-50$ billion & 25 & 20.83 \\
\hline 3. Large Business & $>10$ billion & $>50$ billion & - & - \\
\hline \multicolumn{3}{|c|}{ Total } & 120 & 100 \\
\hline
\end{tabular}

As the proposed measurement for this study should clear about reliability and validity assumptions, PLS-SEM was used to confirm the assumptions. Based on PLS-SEM, as recommended by Hair et al. (2014), composite reliability and Cronbach's $\alpha$ are determined reliability, then for all of the items should be greater than 0.70 . In this study all variables possess high composite reliability value of: 0.899 (knowledge management capability), 0.947 (marketing innovation), 0.852 (product innovation), 0.861 (process innovation), 0.886 (service innovation), and 0.869 (firm performance). Furthermore, Cronbach's $\alpha$ for all variables possess values of: 0.870 (knowledge management capability), 0.922 (marketing innovation), 0.742 (product innovation), 0.785 (process innovation), 0.806 (service innovation), and 0.796 (firm performance). All of these values were considered to be acceptable and confirm an adequate reliability. To ensure validity indicates that a set of indicators represents the same underlying construct, which can be demonstrated through their unidimensionality. The validity of the discriminant variables was proven by calculating the average value of extraction (AVE) and the value obtained between variables. The AVE value for all of the variables was greater than 0.5 , indicating that the variable has sufficient convergent validity (Hair, 2019). Further, each of the variables were measured and possess value of: 0.561 (knowledge management capability), 0.820 (marketing innovation), 0.658 (product innovation), 0.607 (process innovation), 0.722 (service innovation), and 0.629 (firm performance). That average variance extracted (AVE) is a measure of communality for each latent variable (Chin 1998) and indicated adequate result as all of the variance show exhibit value above 0.50 respectively. Thus, the construct measurements of this research are indicated to be robust (See Fig. 3).

This study has nine hypotheses which relevant tested utilizing statistical approach by PLS-SEM. It determines for model-fit and path coefficient as magnitude were used in determining overall relationship effect in the model. As regard sequential partial models were determined for running the statistical analysis. So, in the first hypotheses, the effect of knowledge management capability was tested with marketing innovation and resulting in coefficient of determination $\left(\mathrm{R}^{2}\right)$ of 0.564 . It was determined the relationship between knowledge management capability on marketing innovation showed positive and significant effect $(\mathrm{MI}=0.751$, p-value $<0.05)$ and hence $\mathrm{H} 1$ was accepted. Second hypothesis, the effect of knowledge management on product innovation was tested and the result showed that positive and significant $(\mathrm{PdI}=0.736, \mathrm{p}$-value $<0.05)$ to conclude acceptance $\mathrm{H}_{2}$. Whereas the third hypothesis gives results on the relationship of knowledge management capability to process innovation and shows that it has a positive and significant effect ( $\mathrm{PsI}=0.793$, p-value $<0.05)$, so that $\mathrm{H}_{3}$ can be accepted. In addition, the fourth hypothesis also shows the same results that knowledge management capability on service innovation has a positive and significant effect $\left(\mathrm{SI}=0.717\right.$, $\mathrm{p}$-value $<0.05$ ), so $\mathrm{H}_{4}$ is accepted. Different results are shown in the effect of the relationship between knowledge management capability on firm performance, product innovation on firm performance, and service innovation on firm performance, that in each of these relationships the effect is not significant ( $p$-value $>0.05)$, so that $\mathrm{H}_{5}, \mathrm{H}_{7}$, and $\mathrm{H}_{9}$ is not accepted (see Table 4). Meanwhile, the results of testing the relationship between marketing innovation 
and process innovation on firm performance show a positive and significant effect (p-value $<0.05$ ), then $\mathrm{H}_{6}$ and $\mathrm{H}_{8}$ are accepted. Table 3 also presents the mediating role of the type of innovation from knowledge management capability towards firm performance, which the implications will also be discussed.

Table 2

Reliability and Validity Analysis

\begin{tabular}{|c|c|c|c|c|c|c|c|}
\hline Variable & Item & Mean & $\begin{array}{l}\text { Standard } \\
\text { Deviation }\end{array}$ & $\begin{array}{c}\text { Outer } \\
\text { Loading }\end{array}$ & Cronbach's Alpha & $\begin{array}{l}\text { Composite } \\
\text { Reliability }\end{array}$ & $\begin{array}{c}\text { Average } \\
\text { Variance } \\
\text { Extracted }(A V E)\end{array}$ \\
\hline \multirow{8}{*}{$\begin{array}{c}\text { Knowledge } \\
\text { Management } \\
\text { Capability }\end{array}$} & KMC1 & 3.95 & 0.751 & 0.715 & & & \\
\hline & KMC2 & 4.142 & 0.567 & 0.754 & & & \\
\hline & KMC3 & 4.158 & 0.707 & 0.761 & & & \\
\hline & KMC4 & 3.733 & 0.91 & 0.720 & & & \\
\hline & KMC5 & 4.133 & 0.618 & 0.790 & & & \\
\hline & KMC6 & 4.158 & 0.73 & 0.755 & & & \\
\hline & KMC7 & 3.708 & 0.926 & 0.745 & & & \\
\hline & & 3.996 & & & 0.870 & 0.899 & 0.561 \\
\hline \multirow{5}{*}{$\begin{array}{l}\text { Marketing } \\
\text { Innovation }\end{array}$} & MI1 & 3.975 & 0.811 & 0.726 & & & \\
\hline & MI2 & 4.125 & 0.781 & 0.967 & & & \\
\hline & MI3 & 4.108 & 0.783 & 0.959 & & & \\
\hline & MI4 & 4.067 & 0.772 & 0.947 & & & \\
\hline & & 4.068 & & & 0.922 & 0.947 & 0.820 \\
\hline \multirow{3}{*}{ Product Innovation } & PdI1 & 3.975 & 0.769 & 0.819 & & & \\
\hline & PdI2 & 4.142 & 0.552 & 0.769 & & & \\
\hline & $\mathrm{PdI} 3$ & 4.108 & 0.772 & 0.844 & & & \\
\hline & & 4.075 & & & 0.742 & 0.852 & 0.658 \\
\hline \multirow{4}{*}{ Process Innovation } & PsI1 & 3.942 & 0.778 & 0.768 & & & \\
\hline & PsI2 & 4.108 & 0.589 & 0.783 & & & \\
\hline & PsI3 & 4.117 & 0.787 & 0.798 & & & \\
\hline & PsI4 & 3.733 & 0.929 & 0.766 & & & \\
\hline & & 3.975 & & & 0.785 & 0.861 & 0.607 \\
\hline \multirow{3}{*}{ Service Innovation } & SI1 & 3.917 & 0.822 & 0.765 & & & \\
\hline & SI2 & 4.067 & 0.68 & 0.870 & & & \\
\hline & SI3 & 4.017 & 0.816 & 0.907 & & & \\
\hline & & 4.0 & & & 0.806 & 0.886 & 0.722 \\
\hline \multirow{5}{*}{ Firm Performance } & FP1 & 4.1 & 0.735 & 0.874 & & & \\
\hline & FP2 & 3.75 & 0.924 & 0.705 & & & \\
\hline & FP3 & 4.142 & 0.567 & 0.666 & & & \\
\hline & FP4 & 4.083 & 0.737 & 0.900 & & & \\
\hline & & 4.018 & & & 0.796 & 0.869 & 0.629 \\
\hline
\end{tabular}

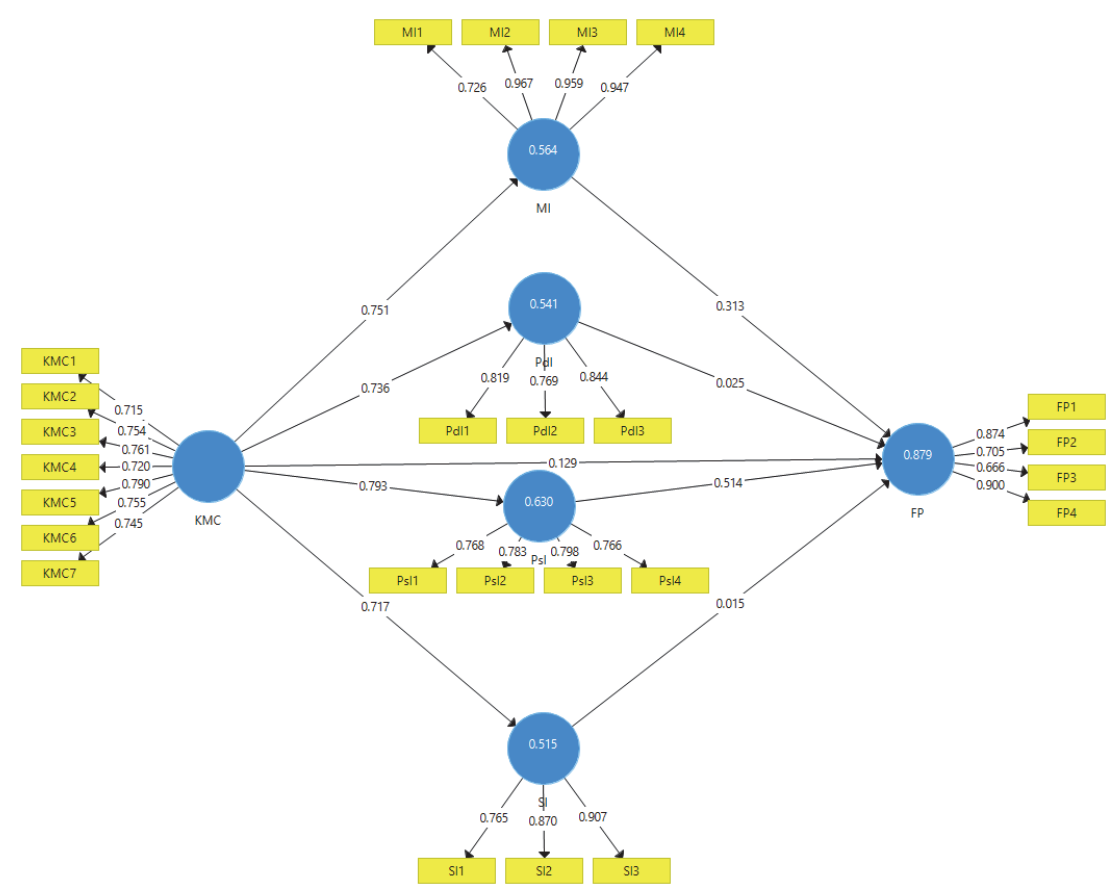

Fig. 3. The results of path efficient coefficients 
Table 3

The summary of the results of testing the hypotheses

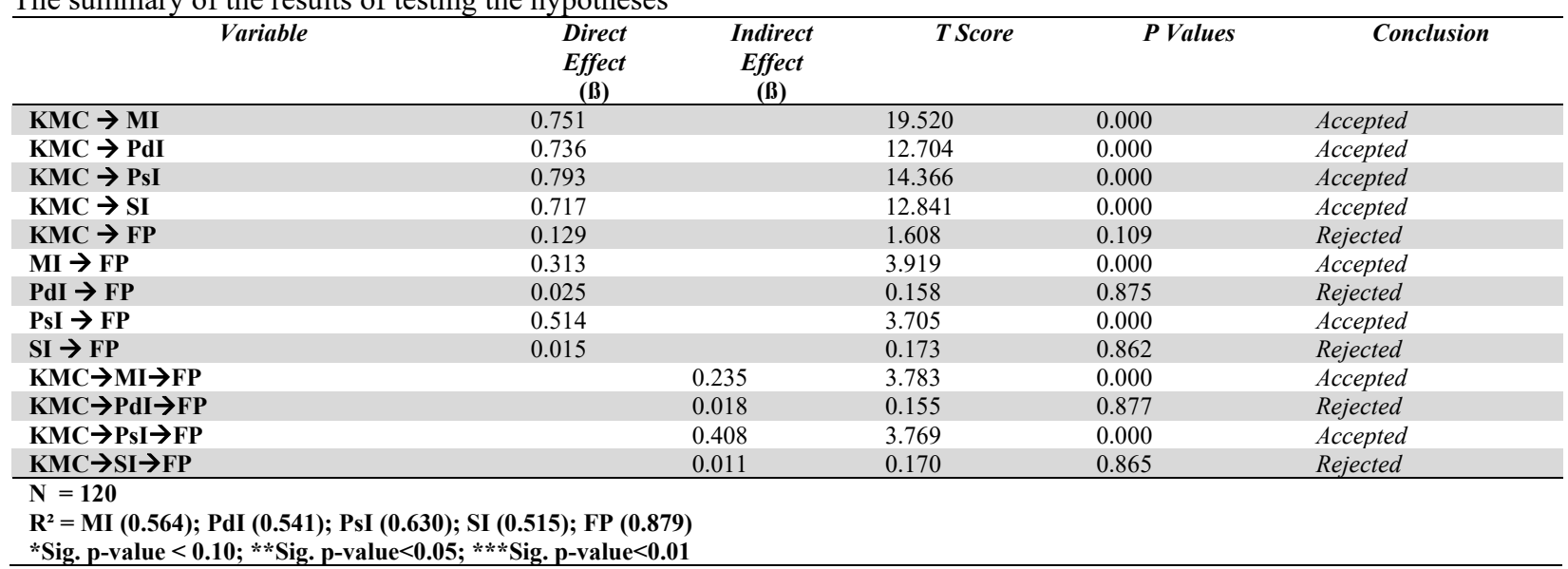

\section{Discussion}

In this study, the aim of this research was to explain the effect of knowledge management capability which is seen when knowledge is used as a resource to improve company performance through the types of innovations (product, process, service, and marketing) that are created. This study indicates that knowledge management capability positively affects firm performance $\left(\beta=0.129, \mathrm{R}^{2}=0.879\right.$, $\mathrm{p}$-value $\left.=0.109\right)$ but it is not significant. Although knowledge can be one of the drivers for company performance, along with limited resources and time, Huizingh (2011) argues that the risk of failure is a critical factor that must be considered as a potential barrier to implementing this knowledge practice. The basis of knowledge management capability is managing knowledge to improve company performance from the results of the innovations created (Cheng and Shiu, 2015; Martinez-Conesa et al., 2017). In the knowledge management process, there is a high risk of failure in managing various knowledge processes, even in large companies and the manufacturing sector often experiences failure in managing knowledge (Exposito \& Sanchis-Llopis, 2019).

Consistent with this perspective, Soto-Acosta et al. (2016) suggest that, to successfully implement knowledge, the complementary nature of internal and external knowledge processes requires integrative knowledge management (KM). In addition, companies need to reconfigure and realign their knowledge capabilities to suit the changing environment (Karkoulian et al., 2013). This draws attention to the importance of knowledge management capability for successfully implementing innovations of various kinds. Knowledge management capability is a dynamic capability that refers to a company's ability to dynamically manage its knowledge base from time to time by reconfiguring and realigning the process of knowledge exploration, retention and exploitation within and outside the organization (Grillo et al., 2018; Santoro et al., 2018). Of the various factors that can explain the failure of knowledge management capability, SMEs need to integrate knowledge and adapt to an increasingly dynamic environment, as in some of the same studies (Karkoulian et al., 2013; Martinez-Conesa et al., 2017; Grillo et al., 2018; Santoro et al., 2018).

Regarding knowledge management capability of the type of innovation, both in terms of marketing $\left(\beta=0.751, \mathrm{R}^{2}=0.564\right)$, product $\left(\beta=0.736, R^{2}=0.541\right)$, process $\left(\beta=0.793, R^{2}=0.630\right)$, and service $\left(\beta=0.717, R^{2}=0.515\right)$ innovation will be a competitive strategy to increase competitive advantage. Companies as institutions for the production of goods and services need to reconfigure their products and practices in order to survive (Mamun, 2018). Thus, the persistent need for different products and services requires (continuous) innovation and a well-planned knowledge management system (Inkinen et al., 2015). The Knowledge-Based View literature reveals that market information is an important component of knowledge-based resources (Morgan et al., 2003). Therefore, knowledge gives companies a sustainable competitive advantage through its application in new or significantly improved products / services, production processes, managerial practices and marketing strategies, namely through innovation (Soto-Acosta et al., 2016). The role of this knowledge management capability enables organizations to develop products, improve employee productivity and performance, improve product quality and customer service, modernize and re-engineer business processes, provide innovative products and services, and increase flexibility (Dahiyat, 2015). Companies by innovating in their processes will be able to create a product and service that is more unique and different than its competitors (Al-Saidi et al., 2017). According to Exposito \& Sanchis-Llopis (2019) knowledge management capability also helps in achieving organizational goals by enabling knowledge and expertise to be easily shared and accessed, as well as promoting the use of available sources of information, skills and experiences. Thus, knowledge management plays a role in facilitating important processes in the organization, namely the learning process (Cammarano et al., 2019). This research reveals that knowledge management capability can have a significant effect on marketing, product, process, and service innovation, just like some previous studies (Al-Saidi et al., 2017; Inkinen et al., 2015; Zhao, 2020). 
In addition, there is an effect of type of innovation on firm performance, the results of this study indicate that only product $(\beta$ $=0.751, \mathrm{p}$-value $=0.875)$ and service $(\beta=0.717, \mathrm{p}$-value $=0.862)$ have no significant effect. Meanwhile, marketing $(\beta=$ $0.751, \mathrm{p}$-value $=0.000)$ and process $(\beta=0.793, \mathrm{p}$-value $=0.000)$ have a significant influence. According to Cabrilo and Dahms (2018), an idea before being implemented is not by itself, but from an innovation process and it must first be developed and transformed into a commercialized product, process or service. Meanwhile, marketing innovation is also a crucial role in being able to distribute the value of a new product or service to the market (Ramadani et al., 2019). This study reveals that efficient process innovation can control all changes that occur in processing methods so as to improve the quality of goods, allowing flexibility in production functions, labor productivity, resulting in competitive advantage, sustainability and performance for companies (Rowley et al., 2011; Rajapathirana \& Hui, 2018). Meanwhile, marketing innovation is closely related to pricing strategies, product design properties, product placement, and promotional activities (Gunday et al., 2011). This is due to the existence of the internet of things which can encourage higher marketing activities (Santoro et al., 2018; Quaye \& Mensah, 2019). However, these other types of innovation do not necessarily guarantee a significant effect on company performance, which can be caused by various factors. These factors later the company, especially in the context of SMEs in this study, must learn why the type of innovation that has been applied cannot work significantly on company performance. According to Mamun (2018) this may be influenced by a market orientation that is not in accordance with the product or service innovation, and even a strategic orientation can have a more dominant effect. Strategic orientation is a way for companies to respond to business challenges, which aligns internal capacity with external environmental factors (Mamun, 2018). Meanwhile, market orientation refers to the tendency of companies to acquire, disseminate and respond to market information to increase their capacity to develop products and service strategies that are appropriate to meet customer needs and requirements (Baker \& Sinkula, 2009). Furthermore, in line with internal resources and a dynamic industrial situation, a strategic orientation builds the strategic adaptability of a company, which leads to greater innovative capacity and superior performance and sustainability (Kumar et al., 2012). These findings confirm the important role of strategic orientation, which represents the direction of SMEs and the application of competitive challenges by obtaining, disseminating and responding to market information, along with the capabilities of SMEs (Mamun, 2018). The aim is to provide superior value to customers and methods, practices, and decision-making styles that are directed at the tendency of companies to exploit new opportunities, in this type of innovation (Baker \& Sinkula, 2009; Mamun, 2018). Of course, this will be closely related when the results of product and service innovation can have a significant effect, but they don't, so this research agrees with research from Mamun (2018).

\section{Conclusion}

This study highlights two important objectives of the hypothesis testing results that give rise to findings. First, these results provide a different significance effect between knowledge management capability on firm performance. The extent to which the influence of knowledge management capability on firm performance may be influenced by the existence of an increasingly dynamic environment, so that organization learning could become a predictor variable to determine the successful implementation of knowledge (Exposito \& Sanchis-Llopis, 2019). In fact, Soto-Acosta (2016) further highlights the failure of knowledge implementation due to the lack of integration of the knowledge management process. From the two, it may be possible for further research to be able to examine the effect of knowledge, both capability and process, on firm performance. Then the second is the result of product and service innovation which has no significant effect on firm performance. This study considers that product and service innovation cannot have a significant impact on company performance, possibly due to a strategic orientation. Agree with Mamun (2018) in his research that a strategic orientation has an impact on products and services and will have a significant effect on firm performance. A strategic orientation builds the strategic adaptability of a company, which leads to greater innovative capacity as well as superior performance and sustainability (Kumar et al., 2012).

\section{References}

Altuntas, S., Cinar, O., \& Kaynak, S. (2018). Relationships among advanced manufacturing technology, innovation, export, and firm performance. Kybernetes, 47(9), 1836-1856.

Al-Sa'di, A. F., Abdallah, A. B., \& Dahiyat, S. E. (2017). The mediating role of product and process innovations on the relationship between knowledge management and operational performance in manufacturing companies in Jordan. Business Process Management Journal, 23(2), 349-376.

Baker, W. E., \& Sinkula, J. M. (2009). The complementary effects of market orientation and entrepreneurial orientation on profitability in small businesses. Journal of small business management, 47(4), 443-464.

Barney, J. (1991). Firm resources and sustained competitive advantage. Journal of management, 17(1), 99-120.

Birkinshaw, J., Hamel, G., \& Mol, M. J. (2008). Management Innovation. Academy of Management Review, 33(4), 825-845.

BPS. (2019). Laporan Perekonomian Indonesia 2019.

Cabrilo, S., \& Dahms, S. (2018). How strategic knowledge management drives intellectual capital to superior innovation and market performance. Journal of Knowledge Management, 22(3), 621-648.

Cammarano, A., Michelino, F., \& Caputo, M. (2019). Open innovation practices for knowledge acquisition and their effects on innovation output. Technology Analysis \& Strategic Management, 31(11), 1297-1313.

Caputo, F., Garcia-Perez, A., Cillo, V., \& Giacosa, E. (2019). A knowledge-based view of people and technology: directions for a value co-creation-based learning organisation. Journal of Knowledge Management, 23(7), 1314-1334. 
Dahiyat, S. E. (2015). An integrated model of knowledge acquisition and innovation: examining the mediation effects of knowledge integration and knowledge application. International Journal of Learning and Change, 8(2), 101-135.

Dahlander, L., \& Gann, D. M. (2010). How open is innovation?. Research policy, 39(6), 699-709.

Expósito, A., \& Sanchis-Llopis, J. A. (2019). The relationship between types of innovation and SMEs' performance: A multidimensional empirical assessment. Eurasian Business Review, 9(2), 115-135.

Ferraresi, A. A., Quandt, C. O., dos Santos, S. A., \& Frega, J. R. (2012). Knowledge management and strategic orientation: leveraging innovativeness and performance. Journal of Knowledge Management, 16(5), 688-701.

Foss, N. J., Lyngsie, J., \& Zahra, S. A. (2013). The role of external knowledge sources and organizational design in the process of opportunity exploitation. Strategic Management Journal, 34(12), 1453-1471.

Gardner, H. K., Gino, F., \& Staats, B. R. (2012). Dynamically integrating knowledge in teams: Transforming resources into performance. Academy of Management Journal, 55(4), 998-1022.

Gassmann, O., \& Keupp, M. M. (2007). The competitive advantage of early and rapidly internationalising SMEs in the biotechnology industry: A knowledge-based view. Journal of World Business, 42(3), 350-366.

Grant, R. M. (1996). Toward a knowledge-based theory of the firm. Strategic Management Journal, 17(S2), 109-122.

Grillo, C., Ferreira, F. A., Marques, C. S., \& Ferreira, J. J. (2018). A knowledge-based innovation assessment system for small-and medium-sized enterprises: adding value with cognitive mapping and MCDA. Journal of Knowledge Management, 22(3), 696-718.

Gronum, S., Verreynne, M. L., \& Kastelle, T. (2012). The role of networks in small and medium-sized enterprise innovation and firm performance. Journal of Small Business Management, 50(2), 257-282.

Guillen, M. F. (2000). Business groups in emerging economies: A resource-based view. Academy of Management Journal, 43(3), 362-380.

Hair, J. F., Ringle, C. M., \& Sarstedt, M. (2014). Partial least squares structural equation modeling: Rigorous applications, better results and higher acceptance. Long range planning, 46(1-2), 1-12.

Hair, J. F., Sarstedt, M., \& Ringle, C. M. (2019). Rethinking some of the rethinking of partial least squares. European Journal of Marketing, 53(4), 566-584.

Helfat, C. E., \& Peteraf, M. A. (2003). The dynamic resource-based view: Capability lifecycles. Strategic Management Journal, 24(10), 997-1010.

Hock-Doepgen, M., Clauss, T., Kraus, S., \& Cheng, C. F. (2020). Knowledge management capabilities and organizational risk-taking for business model innovation in SMEs. Journal of Business Research.

Inkinen, H. T., Kianto, A., Vanhala, M. (2015). Knowledge management practices and innovation performance in Finland. Baltic of Journal Management, 10(4), 432-455.

Karkoulian, S., Messarra, L. C., \& McCarthy, R. (2013). The intriguing art of knowledge management and its relation to learning organizations. Journal of Knowledge Management, 17(4), 511-526.

Kogut, B., \& Zander, U. (1992). Knowledge of the firm, combinative capabilities, and the replication of technology. Organization Science, 3(3), 383-397.

Kumar, K., Boesso, G., Favotto, F., \& Menini, A. (2012). Strategic orientation, innovation patterns and performances of SMEs and large companies. Journal of Small Business and Enterprise Development, 19(1), 132-145.

Li, N., Boulding, W., \& Staelin, R. (2010). General alliance experience, uncertainty, and marketing alliance governance mode choice. Journal of the Academy of Marketing Science, 38(2), 141-158.

Mamun, A. (2018). Diffusion of innovation among Malaysian manufacturing SMEs. European Journal of Innovation Management, 21(1), 113-141.

Mardani, A., Nikoosokhan, S., Moradi, M., \& Doustar, M. (2018). The relationship between knowledge management and innovation performance. The Journal of High Technology Management Research, 29(1), 12-26.

Martín-de Castro, G. (2015). Knowledge management and innovation in knowledge-based and high-tech industrial markets: The role of openness and absorptive capacity. Industrial Marketing Management, 47, 143-146.

Martinez-Conesa, I., Soto-Acosta, P., \& Carayannis, E. G. (2017). On the path towards open innovation: Assessing the role of knowledge management capability and environmental dynamism in SMEs. Journal of Knowledge Management, 22(3), 553-570.

Morgan, N. A., Zou, S., Vorhies, D. W., \& Katsikeas, C. S. (2003). Experiential and informational knowledge, architectural marketing capabilities, and the adaptive performance of export ventures: A cross-national study. Decision Sciences, 34(2), 287-321.

Park, E., \& Kwon, S. J. (2018). Effects of innovation types on firm performance: an empirical approach in South Korean manufacturing industry. International Journal of Business Innovation and Research, 15(2), 215-230.

Price, D. P., Stoica, M., \& Boncella, R. J. (2013). The relationship between innovation, knowledge, and performance in family and non-family firms: an analysis of SMEs. Journal of innovation and Entrepreneurship, 2(1), 1-20.

Quaye, D., \& Mensah, I. (2019). Marketing innovation and sustainable competitive advantage of manufacturing SMEs in Ghana. Management Decision, 57(7), 1535-1553. 
Rajapathirana, R. J., \& Hui, Y. (2018). Relationship between innovation capability, innovation type, and firm performance. Journal of Innovation \& Knowledge, 3(1), 44-55.

Ramadani, V., \& Gerguri, S. (2011). Innovations: principles and strategies. Strategic Change, 20(3-4), 101-110.

Ramadani, V., Hisrich, R. D., Abazi-Alili, H., Dana, L. P., Panthi, L., \& Abazi-Bexheti, L. (2019). Product innovation and firm performance in transition economies: A multi-stage estimation approach. Technological Forecasting and Social Change, 140, 271-280.

Rivard, S., Raymond, L., \& Verreault, D. (2006). Resource-based view and competitive strategy: An integrated model of the contribution of information technology to firm performance. The Journal of Strategic Information Systems, 15(1), $29-50$.

Santoro, G., Vrontis, D., Thrassou, A., \& Dezi, L. (2018). The Internet of Things: Building a knowledge management system for open innovation and knowledge management capacity. Technological Forecasting and Social Change, 136, $347-354$.

Schumpeter, J. (1934). The theory of economic development. Harvard University Press. Cambridge, MA.

Schütz, K., Kässer, M., Blome, C., \& Foerstl, K. (2020). How to achieve cost savings and strategic performance in purchasing simultaneously: A knowledge-based view. Journal of Purchasing and Supply Management, 26(2), 100534.

Soto-Acosta, P., Popa, S., \& Palacios-Marqués, D. (2016). E-business, organizational innovation and firm performance in manufacturing SMEs: an empirical study in Spain. Technological and Economic Development of Economy, 22(6), 885904.

Spender, J. C. (1996). Making knowledge the basis of a dynamic theory of the firm. Strategic management journal, 17(S2), 45-62.

Spithoven, A., Vanhaverbeke, W., \& Roijakkers, N. (2013). Open innovation practices in SMEs and large enterprises. Small Business Economics, 41(3), 537-562.

Wadho, W., \& Chaudhry, A. (2018). Innovation and firm performance in developing countries: The case of Pakistani textile and apparel manufacturers. Research Policy, 47(7), 1283-1294.

Wang, D., \& Chen, S. (2013). Does intellectual capital matter? High-performance work systems and bilateral innovative capabilities. International Journal of Manpower, 34(8), 861-879.

Wu, L., \& Chen, J. L. (2014). Knowledge management driven firm performance: the roles of business process capabilities and organizational learning. Journal of Knowledge Management, 8(6), 1141-1164.

Zhao, J. (2020). Knowledge management capability and technology uncertainty: driving factors of dual innovation. Technology Analysis \& Strategic Management, 1-14.

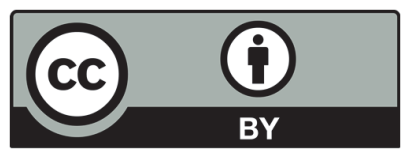

(C) 2021 by the authors; licensee Growing Science, Canada. This is an open access article distributed under the terms and conditions of the Creative Commons Attribution (CC-BY) license (http://creativecommons.org/licenses/by/4.0/). 